Pregledni znanstveni rad DOI: $10.17234 /$ Croatica.63.2 UDK: 821.163.42.09Krmpotić, V.

821.163.42.09-1

Primljen: 20. XII. 2018.

Prihvaćen: 22. II. 2019.

\title{
. \\ TUĐOST PJESME (LIRIKA VESNE KRMPOTIĆ)
}

\author{
Tamara Bakran \\ Poslijediplomski sveučilišni doktorski studij \\ Hrvatska filologija u interkulturnom kontekstu, \\ Filozofski fakultet Sveučilišta u Zagrebu, \\ tbakran@ffzg.hr
}

Rad se bavi odnosom žudnje za transcendencijom i jezika lirike Vesne Krmpotić kao medija te žudnje. U okviru rada promišlja se utjecaj žudnje za transcendencijom na sam pjesnički jezik te se postavlja pitanje što je, u konačnici, (ozbiljivi) objekt pjesničke žudnje. U osnovi je autoričin lirski svijet oblikovan tako da lirsko ja žudi da mu se otkrije Tajna, da Tajna postane Znanje. Tajna se u radu tumači kao Drugo pjesme, (prisna) tuđost, kao ono što jest, ali se ne zna što jest. Tajna je izvan jezika, ali djeluje na jezik, jezik je uprizoruje, ali je ne može razriješiti, ona je i učinak jezika, u uskoj je vezi s pjesmom. Tajna se pritom ne veže uz znanje, već uz slutnju. Za razliku od navedenog shvaćanja toga pojma, u autoričinoj lirici Tajna je izjednačena s Glasom koji diktira Istinu. U radu se propituju posljedice takvog pristupa Tajni na lirski opus Vesne Krmpotić i uopće na razumijevanje i interpretaciju lirike. Dovodeći u vezu žudnju za transcendencijom i pjesmu, na tragu autoričine ideje o tuđosti izvora pjesme, u rad se uvode misli zapadne filozofije (Platon, Heidegger), što je novina u odnosu na dosadašnje kritičke tekstove koji su se uglavnom osvrtali na istočnu filozofiju. Pritom se ne izostavljaju ni suvremeni teorijski pristupi lirici i književnosti (Clark, Culler, Furniss, Bath), kao svojevrsna antiteza kulturnoj tradiciji koja pjesničko stvaranje povezuje s pseudobožanskom djelatnošću.

Ključne riječi: Tajna, Drugo, tuđost, glas, dah, žudnja za transcendencijom, pjesnički jezik, pjesnička zbilja, iskazivo, neiskazivo 
Vesna Krmpotić stupa na pjesničku scenu 50-ih godina 20. stoljeća s krugovašima čiji egzistencijalistički intelektualizam diskretno anticipira. Zbirkom Jama bića (1965) započinje njezina trajna zaokupljenost indijskom duhovnošću, filozofskim zagonetkama i istočnjačkom mistikom. Pisala je i esejistiku i radiodrame, sastavila je i uredila antologije indijskih književnosti i stare egipatske književnosti, kao i tematske antologije spiritualne provenijencije. Prevodila je Vatsyayanu, Erskinea, Caldwella, Steinbecka, Tagorea. Nagrađena je Godišnjom nagradom „Vladimir Nazor” 1975, Nagradom „Vladimir Nazor” za životno djelo 1999, Nagradom HAZU za književnost 2006. za zbirku pjesama 108X108, zatim Odlikovanjem za zasluge u kulturi 2008. te Nagradom „Tin Ujević" Društva hrvatskih književnika za zbirku pjesama Žar-ptica. ${ }^{1}$

Žudnja za transcendencijom, za puninom, za konačnom realizacijom sebstva u onostranom Drugom svojevrsna je tematska opsesija lirike Vesne Krmpotić. Imajući u vidu odnos ja - Ti koji dominira autoričinim opusom, dijelim njezino stvaralaštvo, što je novina s obzirom na postojeća čitanja, na dvije temeljne faze: 1) faza „šutljivog neba” (Gavran 2007: 139), koja traje do 1990, i 2) faza neba koje progovara - koja traje od 1990. Nebo je ovdje metafora za onostranost ${ }^{2}$ kojoj pjesme bivaju upućene, a kasnije i pripisane. U prvoj fazi autoričina stvaralaštva to je nebo bezglasni adresat (Ti), a u drugoj se fazi nebo oglašava pa postaje adresant (Ja). Granica između lirskog ja i lirskog Ja često je zamućena. Tuđost (glasa) se u drugoj fazi autoričina stvaralaštva ističe grafički. Pjesme Drugoga pisane su italikom, a osobna je zamjenica u njima istaknuta velikim slovom.

Iako se autoričine pjesme i žanrovski raznovrsne proze prelijevaju na dijaloge s velikim osobnostima iz vrlo različitih religijskih tradicija, kultura i književnosti, duhovnost njezina pjesništva razvila se poglavito $\mathrm{u}$ sjeni istočnjačkog, vedantinskog ${ }^{3}$ razosobljenja. Vezu s Indijom ne propušta spomenuti niti jedna dosadašnja kritika, ${ }^{4}$ a sama se autorica nebrojeno puta u

* Recenzentima zahvaljujem na konstruktivnim primjedbama. Većinu njih sam pokušala ugraditi u rad. Zbog prirode pristupa problemu i odabrane metodologije neke sam ipak morala ostaviti po strani imajući ih u vidu za buduća čitanja lirike Vesne Krmpotić.

1 Podaci o autorici preuzeti iz Hrvatskog biografskog leksikona (2013).

2 Nebo kao metaforu za nepoznanicu koristi i Heidegger u svom tekstu ...čovjek pjesnički obitava...

3 „Vedantinski vidik koji me odavno bio zatravio kao istina i koji sam prepoznavala u svim misaonim i čuvstvenim ljepotama širom svijeta..." (Krmpotić 1989: 161).

4 „Iako je Vesna otvorena različitim iskustvima, iako je rođena u Dubrovniku, dok joj je 
razgovorima, intervjuima, kao i u prevoditeljskom i književnom stvaralaštvu referirala na Indiju. U ovom se radu pak, suprotno od dosadašnjih čitanja, opredjeljujem za čitanje autoričine poezije u svjetlu zapadne filozofije, $\mathrm{s}$ obzirom na to da je riječ o hrvatskoj pjesnikinji koja piše na hrvatskom jeziku i proizlazi iz hrvatske, odnosno zapadne tradicije i kulture, a i s obzirom na to da žudnju koju zatičem u njezinoj lirici jednako promišljaju i zapadni mislioci. ${ }^{5}$ Moje polje interesa u kontekstu autoričine lirike obuhvaća odnos žudnje za transcendencijom i pjesničkog jezika, fenomen tuđosti u pjesmi te ideju pjesme kao spoznajnog sredstva. U ovom će radu žudnja za transcendencijom i platonski eros biti izjednačeni. Platonov doprinos razumijevanju prirode žudnje za transcendencijom smatram nezaobilaznim za temu kojom se bavim. Naime česti motivi koji se provlače kroz liriku Vesne Krmpotić, poput dvojnosti svijeta, žudnje za spoznajom, ${ }^{6}$ žudnje za nadčulnim, neadekvatnosti čulnog, prisjećanja, žudnje za povratkom k Izvoru, odnosa pjesničkog jezika i zbilje, prisutni su u samoj srži nauka spomenutog mislioca. Gotovo sva poezija Vesne Krmpotić sazdana je od žudnje za istinskim bivstvovanjem koje je onkraj čulnog. Svijet čula u autoričinoj poeziji, baš kao i u Platona, jest svijet privida, sjena, iluzije i on se treba nadići: „Kad strusim sa sebe bjelasanje mesa / i bjesnilo čula, / dal ću biti voćka koja teret stresa / od voća već trula?" (Krmpotić 1983: 38). Istinska je stvarnost u onostranosti i ona ima slične karakteristike kao i Platonov svijet ideja te se do nje dolazi spoznajom koja je ujedno prisjećanje.

Okretanje zapadnoj filozofiji dovodi me do sljedećih pitanja: što žudnja za transcendencijom radi jeziku te zašto je i je li uopće pjesnički jezik najpodesniji za iskazivanje takve žudnje? Na koji način pjesma ostvaruje ili

Beograd godinama i desetljećima domicilna točka, Indija je njeno utočište i posvećeno tlo" (Zima 2012: 187).

5 Autoričina bi se poezija dala povezati is Plotinovom mišlju. Plotin svoj koncept žudnje temelji na žudnji za Jednim, a žudnja za Jednim je osnovni motiv poezije Vesne Krmpotić. Ti je u poeziji Vesne Krmpotić metonimija Jednog i njezina je lirika obilježena mističkom žudnjom za stapanjem s Jednim: „Oh ljubavi, zašto si se razdvojila na njih dvoje? Zar zato da se u svakomu od njih dvoje beskrajno sjećaš svoje jednote?" (Krmpotić 1993: 19). Sv. Augustin se u svojoj misli bavi sučeljavanjem caritasa (žudnje za Bogom) i cupiditasa (žudnje za svijetom), a mnoge autoričine pjesme svjedoče kolebanje upravo između ovih dviju žudnji: „Ja neću taj dvostruki život ljubavni / sa svijetom i s Tobom" (1997: 24).

6 Sunce u njoj drhti kao slika u oku rose, samo od nje rosno: što je drugo ispunjenje, žudnjo, no spoznaja tko smo? (Krmpotić 1983: 38) 
ne ostvaruje tu žudnju? Koje sve žudnje utjelovljuje autoričina lirika? Što bi bilo tuđe pjesme? Je li funkcija poezije spoznajna?

Vesna Krmpotić se sa svjetonazorom koji zastupa u svojim autopoetičkim tekstovima i lirici poglavito nakon 1990. nastavlja na (neo)romantičarsku tradiciju poimanja pjesnika kao medija onostranosti kroz čije pero progovara glas Drugoga, odnosno priklanja se onoj kulturnoj tradiciji koja liriku povezuje s nebeskom pseudobožanskom djelatnošću. U autopoetičkim i metapoetičkim tekstovima često nailazimo na uvjerenje da je upravo pjesma najbolji medij žudnje za spoznajom i sredstvo spoznaje, superiorna bilo kojem drugom obliku izričaja. Iako, sukladno autoričinim iskazima, pjesma nije dostatno sredstvo za pravu, onu nadiskustvenu, izvanjezičnu spoznaju (pjesma je jezična tvorevina te, prema tome, ovostrana i svjetovna), autorica (pogotovo nakon 1990.) pjesmu tumači kao nadosobnu tvorevinu, kao prostor susreta ovostranog i onostranog, prostor u kojem se pojavljuje i ozbiljuje glas Drugoga.

Uvijek sam se osjećala kao olovka u ruci Pjesnika. Nisam razmišljala, premišljala, o čemu pisati. Sjela bih u vlak ili u avion, izvadila bih spremnu bilježnicu, i do kraja vožnje ili leta, knjiga je najčešće bila dovršena - knjiga od preko 400 pjesama...No dodala bih još nešto: takva olovka, pisac, nije tek prazna ploča. Ona je instrument s već ugrađenim pravopisom i sluhovitošću - takvom ja svoje kolege i sebe vidim... ako smo sluhovita olovka čut ćemo Njegovu riječ... On je pisac, mi smo sluhoviti prepisivači (Šalat 2013: 9).

Autoričina pjesma tematizira i samu sebe. Istovremeno pjesma je žalopojka nad nemogućnošću riječi da obuhvati totalitet zbilje. Ona je odraz žudnje za verbalizacijom biti koja vječito izmiče. Sukladno nasljeđu misticizama onostrano je Ti, kojem se obraća lirsko ja, izvanjezična zbilja, nemišljiva i neiskaziva, nedohvatljiva čak i stihovima: „Moja priča o Tebi, to je / cvil riječi koje Te ne mogu slijediti” (Krmpotić 1997: 21).

Jezgra pak Platonove filozofije nauk je o dvjema oblastima - osjetilnoj (svijetu sjena) i mislivoj - koje povezuje upravo eros. Riječima Raphaela Demosa: „Platon prvo dijeli svijet, a onda ga spaja. Eros je princip odnosa” (1934: 337). Za Platona svijet ideja i svijet čula ,stoje jedan pored drugoga, ali nisu jedan s drugim povezani" (Nygren 1953: 170). Prema Barbariću međutim ne radi se o dva svijeta, bivajućem (onom nastajućem i nestajućem) i jestvujućem, nego o dva lica jednog svijeta. Razdvojenost senzibilne $i$ noumenalne oblasti, koja se uglavnom smatrala jezgrom uobičajeno shvaćenog platonizma, Barbarić premješta u drugi plan te navodi kako je upravo međuprostor između tih dviju oblasti s vremenom dospijevao u središte 
Platonovih filozofijskih napora. „Nisu dakle 'dvije oblasti' ono posljednje i najdublje u Platona, već njihova veza, spoj i uzajamni odnos” (Barbarić 1995: 99). U Agotonovoj besjedi eros je doveden u izravnu vezu s pjesništvom: „Svako bar postaje pesnik, 'ako i nije bio sa Muzama pre' ${ }^{7}$ koga se Erot dodene. A ovo zacelo smemo uzimati kao svedočanstvo za to da je Erot uopšte odličan stvaralac u svemu duhovnom stvaralaštvu" (Platon 1970: 62). Žudnja za transcendencijom centralna je točka autoričine poezije, a zametak ideje pjesnika kao medija božanskog, na koju se nastavlja autoričina poezija, nalazimo dakle već u Platona.

Mene međutim u radu zanimaju isključivo značajke Platonova erosa te veza erosa kao tuđeg i poezije. Značajke Platonovog erosa, a ujedno i poveznice između Platonove filozofije i ideje koju sadržava poezija Vesne Krmpotić vidim u sljedećim točkama:

a) eros kao princip odnosa između dviju oblasti od kojih je jedna nedostatna

b) eros kao tvorac (pjesničke) zbilje

c) božansko kao tuđe

d) veza erosa i božanskog

e) veza erosa i poezije

f) veza božanskog i poezije

g) tuđe kao preduvjet autentičnosti

h) ljepota, zanos, inspiracija i pjesma

Po uzoru na Platonov eros kao princip odnosa između dviju oblasti, a vodeći se idejom Vesne Krmpotić da je poezija žudnja za iskazivanjem neiskazivog, ${ }^{8} \mathrm{u}$ radu uspostavljam iskazivo i neiskazivo kao te dvije oblasti, te među njih postavljam pjesničku žudnju. Time dolazim do sljedeće jednadžbe: iskazivo + neiskazivo + žudnja $=$ pjesnička zbilja, te postavljam tezu da pjesma ublažuje rascjep između dviju oblasti, a to se ublažavanje ne događa kao spoznaja nego kao jezična igra ${ }^{9}$ i čitam autoričinu poeziju

7 „Citat iz Euripidove Stenebeje, frg. 663, a hoće da kaže njim: ako se i nije pre bavio pesništvom" (Platon 1970: 208).

8 „A poezija... ona po stotinu-i-tisućiti put želi nemoguće, i u tome je njezina neumorna draž. Poezija bi htjela doprijeti do te konačne riječi vrhovnice, do svesadržajne riječi-majke, do stiha koji je i izvor-i-ušće ljepote i istine. Znalo se ili ne znalo da se to radi, da se od toga ne odustaje, da se u tome ne sustaje, da se za tim žudi” (Krmpotić prema Šalat 2013: 8).

9 Jezičnu ću igru u radu kasnije tumačiti oslanjajući se na Heideggerovu misao. 
kao uprizorenje dviju antagonističkih žudnji - one za mističnom šutnjom i one za totalnom riječju. Ključnoj ideji autoričine poezije o pjesmi kao spoznajnom sredstvu i pjesniku kao privilegiranom mediju onostranosti suprotstavljam tezu koja poriče pjesmi spoznajni i samospoznajni karakter. Također propitujem fenomen glasa i, za razliku od autorice i uvriježenih tumačenja suvremene teorije, tuđost pjesme ne označujem tim pojmom.

U lirici Vesne Krmpotić iskazivo je nedostatno. Iskazivo ne može prekriti svu zbilju, ono ju čak izobličuje. U iskazivom ima cvila, ono nije milozvučno, ono para uši. U cvilu ima jadikovke. U Platona žudnja je tendencija napuštanja neadekvatne zbilje putem spoznaje, u lirici Vesne Krmpotić neadekvatna zbilja je ovostranost (Svijet) i jezik (naročito prozni).

Pjesnici se u stihovima vladaju kao izumiruća vrsta u rezervatima: divljaju s odobrenjem... Pa ipak, kako surovo pjesnik prekida svoju pjesmu kad ukorači u nestihove! Kako se odjednom odrekne razloga kojima vjeruje poezijom! Kako se uplaši svoje iskonske misli kad više nije pod zaštitom rezervata! Ništa ne pomaže što prozu piše ,poetično”: jer sad ispovijeda drugu logiku gledanja, drugačije povezuje stvari, na drugi način čita znakove događaja - te je do te mjere sebi stran kao da njegovo ime pokriva dvije osobe (Krmpotić 1975: 8).

Neadekvatna zbilja se i kod Vesne Krmpotić napušta spoznajom: „Daj mi znanje da jesam to što jesam" (1997: 17). Za razliku međutim od Platona autorica prvenstvo u spoznaji daje pjesničkom umu. ${ }^{10} \mathrm{U}$ čitanju autoričine poezije pritom nailazim na paradoks. Spoznaja se s jedne strane, kako kaže autorica, manifestira mističkom šutnjom ${ }^{11}$ kao napuštanjem neadekvatne zbilje, tj. ovostranosti/jezika. Funkcija pjesme tek je tješiteljska. S druge strane stilizirajući lirsko Ja kao onostranost koja iskazuje Istinu, autorica izjednačuje pjesmu i spoznaju. Ono što premošćuje dvije oblasti (esenciju i egzistenciju, neiskazivo i iskazivo) u kontekstu autoričine lirike jest pjesma kao spoznaja.

Prisutnost tuđosti pak jamac je autentičnosti poezije, uvjerenje je autorice.

10 Ne dopusti da svakodnevni, džepnog formata um, posrami tvoj pjesnički um,

koji je jedini pozvan da Me čuje i kazuje (Krmpotić 1999: 254).

11 NASLUTI ME; I UŠUTI

Nasluti Me; i ušuti.

Um ti nisam dao da mislima šumi,

već da šutljivo sluti svoju srodnost

sa tišinom (Krmpotić 1999: 180). 
Nekada su mi tako, ni sama ne znam kako, padali u krilo gotovi stihovi, pjesme bez grčeva, bez buke. Imala sam osjećaj da nisu moji, da su tuđi odstrijel, i strepila sam čekajući dan kada će se javiti pravi vlasnik. Te pjesme su mi bile tuđe i po tome što ih nisam razumijevala. Ali puštala sam da takve i ostanu - nerazumljive mi - jer se nisam usudila da ih mijenjam, kao što se ne bih usudila krivo prepisati citat tuđe misli. [...] Nisam čak ni znala što se u toj strofi kaže. Strahovala sam da me tko o tome ne upita. I oprezno, vrlo nesigurno, pokazivala sam je drugima. Da stvar bude gora, drugi su je pohvalili; drugi su je nastavili hvaliti; i postala je „antologijska”. S istim čuvstvom hladnoće i krivnje čitala sam je na književnim večerima, navikla da je zovem svojom, ali ne i da je smatram svojom [...] Te ja i one tuđe pjesme, najmojskije, uzesmo se grliti kao poslije duga rastanka (Krmpotić 1975: 40, 41, podcrtala T. B.).

Antologijske su, prema autorici, one pjesme koje su tuđe, a naknadno prepoznate kao najmojskije. U kontekstu lirike Vesne Krmpotić radi se o dvostrukoj tuđosti: pjesme nastaju mimo autoričine intencije (tuđa su volja), autorica ne shvaća što one znače (tuđe joj je značenje). Autorica tu tuđost u svojim pjesmama naposljetku svodi na izvor glasa. U predgovoru zbirke Sedam koraka oko vatre Vesna Krmpotić se pita: „Čiji je glas, taj prekrasni Glas? Glas našeg uma, možda? Glas vrhovne svijesti? Glas Isusa, Budhe, Krišne? Glas Drugog Dolaska? Glas Istinitoga, Sathya Sai Babe? Glas našeg sna? Ili glas puste želje?” (1999: 21, podcrtala T. B.). Drugim riječima, nepoznanica progovara u pjesmi. U kontekstu autoričine lirike ono tuđe/ Drugo poezije lirski je subjekt i porijeklo lirskog subjekta.

U Platona postoji upravo veza žudnje > zanosa $>$ tuđosti $>$ ljepote $>$ poezije. U ovom radu međutim zastupam tezu da se tuđost u Platona nije odnosila na glas koji nastanjuje ili diktira. Sukladno tome tuđost se u ovom radu ne tumači kao glas koji zaposjeda bilo autora bilo tekst bilo čitatelja. ${ }^{12}$

12 I suvremena se teorija opsežno bavila fenomenom glasa u pjesmi, poistovjećujući glas s lirskim subjektom baš kao i sama autorica, $\mathrm{s}$ tom bitnom razlikom što suvremena teorija ne samo da ne pripisuje glas božanskom nego ga ne pripisuje ni autoru. Nema glasa, tek iluzije glasa kao učinka teksta. Mary Jacobus u tekstu Apostrophe and Lyric Voice in the Prelude promišlja glas kao ono što daje ,iluziju jedinstvenog izvora i temporalnog jedinstva” (prema Hošek i Parker1985: 173). Nadalje, spominje „glas kao mit” (isto, 174) ili se pita: „Čiji su glasovi koje pjesnik čuje? Ne nužno njegovi vlastiti, naposljetku” (isto: 174). Pjesnički je dar, kaže, „,̌uti glas” (isto: 175) te postavlja pitanje: „koja je relacija glasa i pisanja?” (isto: 176). I Tilottama Rajan u tekstu Romanticism and the Death of Lyric Conciousness u pitanje dovodi autonomiju glasa, ističe njegovu tekstualnost te dovodi u pitanje ideju govornika „kao ujedinjene osobe koja se realizira kroz svoj jezik" (isto: 197). Herbert F. Tucker u tekstu Dramatic Monologue and the Overhearing of Lyric smatra da tekstovima ne manjka u potpunosti govornik, ali ga niti ne posjeduju u potpunosti. „Tekstovi ne dolaze od govornika, nego govornici nastaju 
Fenomen tuđosti javlja se u Platona kada je riječ o zanosu. U Platonovu Fedru i Ijonu zanos je neizostavni pratilac erosa i poezije. U Fedru su mu posvećena dva poglavlja: A) Zanos ne treba odmah osuđivati i B) Dokaz da je ljubavni zanos izvor najveće sreće. Zanos ${ }^{13}$ se veže uz pojmove inspiracije, entuzijazma ${ }^{14}$ i nadahnuća. Stoga pojam glas zamjenjujem pojmom dah. Time ujedno nastojim oduzeti pjesmi stigmu one koja pokušava nametnuti autoritet, nastaniti čitatelja neželjenim glasom.

Platon zanos stavlja izvan čovjekovih moći, pripisujući ga tuđoj snazi (Muza/Boga). Za lijepo djelo nije toliko bitan čovjekov talent koliko „božanska snaga koja goni” (Platon 1970: 10) jer ,pesnik je naročito biće: on je lak, krilat i svešten, i ne može pevati pre nego što bude ponesen zanosom, pre nego što bude izvan sebe i svoga mirnog razuma" (isto: 11). Pjesnici nisu zanatlije, ali nisu ni autori. ,[...] lepe pesme nisu ljudske ni ljudsko delo, nego božanske i božansko delo" (isto: 12, podcrtala T. B.). Puni zanosa (onog tuđeg ${ }^{15}$ ili u platonskom/mističkom diskursu puni Boga), pjesnici zanos dalje prenose na publiku (slika magneta i prstena u Platonovom djelu Ion). Drugim riječima, pjesma je proizvod tuđega u pjesniku, a to tuđe odlazi i dolazi nevezano uz volju samog pjesnika, baš kao što se i nadaje iz citata Vesne Krmpotić. Tuđe međutim u Platona nije glas nego sila koja se tek ima pretočiti u riječ i to tuđe je u Platona, vidjeli smo, jamac ljepote, a ne istine. Platon u svojem djelu Fedar govori o četiri vrste zanosa: 1. mantika

iz teksta" (isto: 243). Govornici su prema Tuckeru na neki način duhovi stvoreni mašinom, literarni efekt, igra označitelja. Jonathan Culler također naglašava: „Lirski je subjekt konstrukt, funkcija jezika [...] To čitatelj, reagirajući na lirske efekte u tekstu čini ja da govori u pjesmi [...] Lirski subjekt je fikcija [...] Čitatelj pjesme mora se konstantno pitati tko ovdje govori” (1981: 34).

13 zanos $=1$. bunilo, 2. oduševljenje, ushićenje, entuzijazam, zadubljenost entuzijazam = prvobitno je ta riječ označavala stanje čovjeka koji je pun Boga. Danas se ona upotrebljava u značenju oduševljenje, zanos, ushićenje, strastvena zagrijanost za neku stvar ili ideju.

inspiracija $=1$. faza udisanja, udisaj (kada se prsni koš širi i ošit spušta), 2. stanje koje potiče umjetničko stvaranje i znanstvena otkrića; nadahnuće, 3. teol. karizmatički utjecaj Boga na sastavljače Svetog pisma preko kojih Bog postaje u posebnom smislu začetnik tih spisa *lat. inspiratio (Anić, 2000).

14 U filozofijskom rječniku stoji da je prvobitno značenje riječi entuzijazam bilo biti pun Boga. To neodoljivo podsjeća na diskurs mističara koji su smatrali da se ispražnjavanjem od osjećaja, misli (riječi) pripremaju na to da budu ispunjeni Bogom, jedno s Bogom. „Mistična teologija je jedno utjecanje Boga u dušu” i nauk o mističnom iskustvu je „vrlo slastan i zanosan” (Johnston 2007: 97, 98).

15 No to tuđe u diskursu mističara nije potpuno tuđe. Ono se svodi na paradoks ,poznato nepoznato" (Toma Akvinski). 
(vještina proricanja), 2. ojonistika (vještina promatranja ptica), 3. zanos, ili pomama, koji dolazi od Muza i 4. eros, najplemenitiji od zanosa. Poezija je povezana s 3. tipom zanosa.

Treći oblik zanosa i pomame jeste onaj što dolazi od Muza. Kad on zahvati nežnu i čistu dušu, on je podstiče i zadahnjuje pesmama i drugim vrstama pesništva, i ona, slaveći neizbrojna dela predaka, poučava potomstvo. Ali ko se bez nadahnuća Muza približi dverima pesničkog stvaralaštva, misleći da će moći svojom veštinom postati valjan pesnik, taj ostaje šeprtlja, i njegovu poeziju, kao razumsku stvar, pomračuje poezija onoga koji peva u zanosu (Platon 1970: 132). ${ }^{16}$

Sasvim drugačije konotacije ima ideja biti ispunjen božanskim dahom od ideje biti ispunjen božanskim glasom. Ostaje pitanje mogu li se tuđa volja za riječima (glas) u lirici Vesne Krmpotić i tuđa sila (dah) u Platonovoj filozofiji staviti pod isti nazivnik - tuđosti kao izvora lijepe, autentične pjesme? Tuđa je volja u autoričinoj lirici prikazana kao božja volja (volja Jednog) i autorica je mora provoditi. Lirski subjekt je čas stiliziran kao glas Jednoga ${ }^{17}$ čas kao glas dvojine. Pjesme se množe. Glas diktira u sluhovitu pisaljku. Dah je, za razliku od glasa, neodređen, neomeđiv, nematerijalan pa je, po mojem mišljenju, prikladniji za imenovanje tuđosti prisutne u pjesmi. Dah ne pripada diskurzivnom dok glas pripada.

U radu su dakle neiskazivo, druga oblast, nebo, aura, strano, nepoznanica, Drugo, Tajna, (prisna) tuđost, dah - sinonimi. Od navedenih pojmova izlučujem pojam Tajna kao onaj koji će od sada prevladavati u tekstu. Tajnu definiram kao ono što jest, ali ne znamo što jest. S obzirom na to da o njoj nemamo znanje niti je možemo iskazati, ona nije diskurzivnog karaktera. Tajna međutim vabi da se iskaže. Tajnu slutimo. Slutimo je i stoga je Tajna prisna tuđost, a ne radikalna tuđost. Radikalna se tuđost ne bi mogla slutiti, a puka se prisnost zna. Inzistiranjem na pojmu Tajna, i to pisanim velikim početnim slovom, nisam željela pjesmu pripisati onostranosti već samo tuđosti. Tajna bi Heideggerovim riječima bila ,strano uslikano u blisko da bi ostalo strano" (2002: 284), a to je ujedno i njegova definicija biti pjesničkog. Heidegger naime u tekstu ...čovjek pjesnički obitava... (2002)

16 „Strast i izraz neodvojivi su. Izvor strasti je u zanosu duha iz kojeg se rađa jezik. Čim ona nadiđe nagon, čim zaista postane strast, odmah teži da se priča sebi samoj, bilo da se opravda da bi se uzvisila, ili jednostavno pour s'entretenir. [...] Što je čovjek osjećajniji, više ima izgleda da bude govorljiviji i izražajniji. [...] Isto tako, što je čovjek strastveniji, lakše će izmišljati pjesničke figure; ponovo otkrivati njihovu nužnost; spontano se izražavati podražavajući 'uzvišeno' koje su one učinile nezaboravnim” (De Rogemont, 1974: 172, 173).

17 Glas Jednoga je paradoks jer glas uvijek već implicira dvojinu, obraćanje udvaja. 
poeziju definira kao omjeravanje s božanskim ${ }^{18}$, na što se doista može svesti čitav autoričin opus. Lirsko ja se omjerava s božanskim Ti, pokušava iznaći svoju poziciju u odnosu na božansko, „Svuda sebe vidim Tvojim pogledom” (Krmpotić 1997: 31), te se to omjeravanje očituje pjesmom. No autorica iskazivo i Tajnu povezuje tako što stilizira lirski subjekt kao Glas onostranosti. Prozopopeja postaje glavni, ako ne i jedini, znak onog božanskog u pjesmi. Tajna samu sebe iskazuje kao Istinu. Heidegger na drugačiji način međutim tumači pjesničko povezivanje Tajne i iskazivog kad kaže: „Pjesničke slike nisu puke fantazije i iluzije, nego u-slikavanja kao zamjetljiva stavljanja onog stranog u prizor onog bliskog” (2002: 284, podcrtala T. B.), „Pjesnik u bliskim pojavama doziva ono strano kao ono čemu se ono nevidljivo prilagođuje da bi ostalo ono što jest: nepoznato" (isto: 284). Prema tome pjesničko umijeće, prema Heideggeru, svodilo bi se na uslikavanje, tj. na umijeće ulančavanja označitelja na takav način da uprizoruju strano ne razrješujući ga. Pjesnički dar ne bi dakle bio dar slušanja Glasa niti zapisivanja njegovog diktata niti spoznaja istine, nego dar u-slikavanja stranog u blisko. $\mathrm{U}$ ovom radu upravo tu tuđost integriranu u pjesmu označujem pojmom Tajna, za razliku od autorice koja tuđost $u$ drugoj fazi stvaralaštva svodi na Glas (lirski subjekt), iz čega slijedi da je ozbiljeni objekt pjesničke žudnje ili teoza ili čudo iskazivanja neiskazivog što, po mojem shvaćanju, pjesmu prije pretvara u sredstvo, a ne svrhu.

Neiskazivo, dakle nediskurzivno, u poeziji žudi pretočiti se u riječ. U toj žudnji međutim uvijek ostaje nešto nedefinirano, taj neki, kako ga Ricoeur zove, višak smisla, nešto što nije svodivo na riječ, na Glas, na Ja. To nešto je prisutno više kao poetska aura riječi (prema Valdes 1991: 449). Poslužila bih se dakle Ricoeurovom terminologijom u konačnom definiranju Tajne $u$ svom radu. Tajna je u pjesmi prisutna kao poetska aura riječi. Rascjep se ublažuje stvaranjem riječi koje su obavijene aurom, ali te riječi nisu nositeljice spoznaje niti u potpunosti prekrivaju cjelokupnu zbilju. Zašto pjesma

18 Božansko je u Heideggera nepoznanica. Heidegger navodi sljedeći Hölderlinov stih: „On [Bog] je mjera ljudska” (isto: 278). „Bît 'pjesničkoga' Hölderlin vidi u uzimanju mjere kojim se vrši premjeravanje čovjekove bîti" (isto: 280). Mjera je Bog s kojim se čovjek omjerava. No tko je Bog? „Možda je to pitanje preteško za čovjeka i prenaglo?” (isto: 283). Na pitanje pak Što je Bog?, Hölderlin odgovora stihom: „On je mjera ljudska”. „Je li Bog nepoznat? (isto: 281). I kako kao nepoznat bog może biti mjera? Pa ipak, Bog je kao onaj koji jest za Hölderlina nepoznat; $i$ kao taj nepoznati, on je upravo mjera za pjesnika” (isto). Ovakvo poimanje Boga najbliže je mističkom poimanju Boga kao poznato nepoznatog. „Boga se zna kao neznanog (quasi ignotus cognoscitur). Boga se zna kao misterij” (Johnston 2007: 55). 
nije spoznaja? Pjesma, kaže Ricoeur, za razliku od sna, otkriva. San skriva. Međutim i pjesničko otkrivanje istovremeno sadrži neku „neprozirnost” (opaqueness) (isto: 460), ,zato što je jedan način otkrivanja istovremeno i činjenje više opskurnim" (isto: 460). Ta je neprozirnost (u ovom radu Tajna) tek uprizorena pjesničkim ulančavanjem riječi ${ }^{19}$ koje potencira polisemiju, širi doseg riječi. Tajna je riječima nagoviještena, nije razriješena. Alkemija daha u riječ razlikuje se od slušanja diktata Glasa. Prvo podrazumijeva kreativni čin, drugo poslušnost. U drugoj fazi autoričine lirike žudnju za iskazivanjem neiskazivog poništava diktirajući Glas. Sve postaje (do)govor.

O pojavi pjesmenih poruka reći ću samo to, da su one počele u svibnju 1990., i da su otada u prosjeku zapisivane po deset zbirki (od 108 pjesama) godišnje. [...] O karakteru njihovu smijem reći da su one samostalan, nezaustavljiv, bespogovoran dogovor Jednine s Dvojinom, i da „mojim” smatram samo jezik i stil autorice Vesne Krmpotić, dok autoritet kazanog doživljavam nadosobnim (Krmpotić 1999: 15, podcrtala T. B.).

Iz ovog se citata vidi na koji način pojam glas uz sebe neizostavno veže i pitanje autoriteta. Upravo to što se izvor teksta pripisuje božanskom suvremena čitanja s pravom prepoznaju kao pokušaj uspostave neprikosnovenog autoriteta teksta, a vrlo često i građanske osobe autora. Glas autoriteta/uljez želi nastaniti, oplemeniti ili prosvijetliti čitatelja. Pritom se čitatelj svodi na pasivnog primatelja poruke kojem nedostaje nešto što mu tekst tek treba dati. „Romantična koncepcija inspiracije često se hrva sa najnevjerojatnijom idejom arhaičnog utiska - da pisac ima najviše autoriteta kad najmanje zna što radi" (Clark, 2000: 3).

Nadalje dok mistička šutnja podrazumijeva radikalno napuštanje jezika, pjesnička žudnja stremi k totalnoj riječi. Riječ-vrhovnica nije objekt koji bi se mogao ozbiljiti. No neiskazivo, iako nedosežno, jest djelatno. U nemogućoj žudnji da se zateknutim jezikom iskaže Tajna, riječi se ulančavaju na novi, jedinstveni način. Zbiva se transcendencija jezika, tj. dato jezika prelazi, dijalektički, u novo jezika. ${ }^{20}$ Jedinstveno ulančavanje označitelja također

19 No ova neprozirnost nikako ne znači proizvoljnost značenja ili čak njegovo nepostojanje. Ricoeur kaže: „Tekstovi u sebi sadržavaju snagu vjerovanja u ono što je rečeno i snagu da to kažu komu s nakanom da ga dosegnu" (prema Brnčić 2012: 42).

20 Furniss i Bath u tekstu Poetic metaphor navode Shelleyevo mišljenje kako ,nove metafore proizvode nove misli [...] pjesnici revitaliziraju jezik [...] poetičke metafore čine jezik živim" (2007: 117). Ulazeći u gotov jezik, u čvrste i nametnute strukture označitelj - označeno, subjekt osjeća tjeskobu ukalupljivanja sebstva. Pjesnički jezik, razlabljivanjem, transcendiranjem tih struktura kako bi uprizorio i ono neiskazivo (neiskazano), generira užitak. Furniss i Bath, 
proizvodi tajanstveno označeno. Tajna tako postaje izvor i ušće pjesničke riječi. Sukladno tome ozbiljeni objekt pjesničke žudnje, moja je teza, nije totalna riječ ni (mistička) spoznaja, već transformirana riječ, riječ s aurom, dalekosežnija riječ, proširena (jezična) zbilja, riječ kojom naslućujemo Tajnu.

Imajući sve ovo u vidu, moglo bi se reći da se u lirici Vesne Krmpotić, među ostalim, događa supostojanje antagonističkih žudnji: žudnje za radikalnim raskidom s riječi (mistička žudnja za šutnjom) i žudnje za riječi (pjesnička žudnja). Svaka od tih dviju žudnji u autoričinoj lirici sabotira onu drugu. Dok god se žudi za riječi, ne može se postići mistička šutnja, s druge strane, čini se kao da u autoričinoj lirici silna žudnja za mističkom šutnjom sili pjesmu na iskazivanje Tajne kao Istine. Znači ono nemoguće autoričine poezije, moje je mišljenje, nije žudnja za iskazivanjem neiskazivog, nego žudnja da Tajna samu sebe putem pjesme iskazuje kao Istinu. Slutnja prelazi u znanje. Mističnost pjesme više nije sadržana u onom kako se govori, nego u onom tko govori i što govori. U tom procesu, moje je mišljenje, pjesme Vesne Krmpotić gube na svojoj liričnosti. S obzirom na to da se Tajna svela na Glas koji iskazuje Istinu te je time Tajna prestala biti Tajna, ono što je postalo radikalno odsutno zapravo je sama Tajna. Time se ukida čitava jedna oblast - neiskazivo. Iako dakle lirika Vesne Krmpotić uspostavlja ideju o radikalnoj razdvojenosti dviju oblasti: „A poezija... ona po stotinu-i-tisućiti put želi nemoguće" (prema Šalat 2013: 8), istovremeno tu ideju negira tako što stilizira lirski subjekt kao Glas onostranosti. Riječ ne može u onostranost, no zato onostranost dolazi do riječi. Onostranost je rječita.

Ova ću promišljanja sada pokušati oprimjeriti analizom dviju autoričinih pjesama, jedne iz prve faze (prije 1990), a druge iz druge faze (poslije 1990). Naime dok prvu fazu uglavnom čine refleksivne i hermetične pjesme čiji je jezik simboličan i slikotvoran, a u zbirkama prevladava ritmičnost, zvonkost zvuka, zvukovne igre, jezična imaginacija i nove, elastične kovanice, poezija druge faze postaje sve ogoljenija, po mojem sudu, od osnovnih

pozivajući se na Barthesa, kažu sljedeće: „Upravo elementi u tekstu koji se opiru prevođenju na literarno značenje, označitelji koji odbijaju predati svoje označeno, polučuju estetske i kognitivne rezultate. Čitatelji mogu doživjeti unikatno zadovoljstvo u čitanju takve poezije koja se ne da izvesti iz reduciranja svakog pojedinog elementa figurativnog jezika na jedno, stabilno značenje. Figure nas intrigiraju upravo zato što se odupiru konačnom značenju" (isto: 156). Da transcendencija može biti ostvarena isključivo na jezičnom planu, a ne kao dosegnuta nad-osjetilna stvarnost, svjedoče upravo pjesme. „Čovjek izvan Svijeta samo je apstrakcija” (Kojeve 1990: 198). „Bez Riječi ne bi Vječnost bila predočena u vremenu i, sljedstveno, ne bi bila pristupačna Čovjeku" (isto: 334 ). 
značajki pjesničkog jezika te se prije da klasificirati kao didaktička nego kao refleksivna. Pjesme druge faze postaju isključivo dijalog množine i jednine, lirskog ja i onostranog, onostranog kao lirskog Ja i zapisivačice.

\section{PREDIGRA}

Na svakom koraku susrećem potpis

te ruke do dna čitke;

kad breze zabreze, sanjarske, vitke,

s mjesecom koji škropi,

kad svibe zasvibe, i pelud poludi

pa krene u mirisnu bitku,

ja čitam pismo kralja što nudi

ljubav, do dna pitku.

Na svakom koraku znaci početka, predigre moga bića;

sa svom zlatninom svadbene tajne

zveckaju spremna otkrića. (Krmpotić 1983)

Pjesma Predigra iz zbirke Vilin svlak pripada prvoj fazi autoričina stvaralaštva. Pjesma je oblikovana u 3 strofe. Rima je nepravilna, stih slobodan. Dinamika na planu izraza uspostavljena je rimom i ritmom, bogata uporaba figura značenjski produbljuje, uslojava pjesmu. Temeljni je motiv susretanje lirskog ja s pismom/potpisom kralja. Iako je kralj antropomorfiziran (ruka koja se potpisuje ili piše pismo), jasno je da veze između označitelja i označenog nisu uobičajene jer se prilikom čitanja ne stječe dojam bilo materijalnosti pisma bilo kralja kao okrunjenog vladara neke države. Posve zagonetno ostaje tko je lirsko ja, tko kralj, kao i to zašto je baš pismo/potpis njegov trag. Pismo je sveprisutno, s obzirom na iskaz na svakom koraku koji se ponavlja dva puta. U pjesmi ne postoje jasne lokalne odrednice. U prvi mah stječe se dojam da se susretanje zbiva vani, noću, no opet moguće je i da se susret, izazvan proljećem, zbiva unutra, na planu bića. Sviba je cvijet po kojem je svibanj dobio ime, priroda je u svojevrsnom deliriju buđenja što se pojačava personifikacijom flore. Istovremeno se uz to mahnito, slavljeničko, proljetno ozračje potencirano glagolima uvođenjem epiteta sanjarske postiže svojevrsna opozicija buđenje - san. U Rječniku simbola (1983) breza se, kao i u pjesmi, povezuje s mjesecom, a simbolizira put kojim nebeska energija silazi i kojim se ljudska težnja uspinje. Proljeće je početak novog ciklusa. 
Naslov pjesme, kao i upotreba epiteta svadbeni, asociraju na svadbenu noć ili čak na neke proljetne obredne svetkovine. Također i sama je predigra početak vođenja ljubavi. Pjesma je dakle sva u znaku obećavajućeg početka.

Flora u proljetnom bunilu može se iščitati i kao metafora razbuđenog jastva. Iako pojam predigra obično podrazumijeva makar dvoje sudionika, iz iskaza predigre moga bića stječe se dojam da je predigra u kontekstu ove pjesme prije samotni čin, što bi imalo upućivati i na svojevrsnu samodostatnost lirskog ja. Nadalje svadbena tajna upućuje na svadbu, ali ne i na čiju. Ne samo da je tajna svadbena, nego je i svadba tajanstvena. Ako pjesmu pak čitamo kao da se radi o svadbi bića i tajne, to onda naznačuje mogući pravac tumačenja pjesme pod utjecajem mističkog nasljeđa. Misticizam kao središnji motiv ima upravo erotski odnos pojedinca $\mathrm{s}$ tajanstvenim onostranim, ljubavnika s ljubljenim. Sâm kralj nije prisutan, već je ostavio svoj/e potpis/pismo kao trag. Odsustvo kralja međutim ne pokreće tužaljku. Ugođaj koji prevladava u pjesmi jest raskoš tajne, svadbene svečanosti, buđenja, slutnje, obilja, nagovještaja promjene i otkrića. Već i sam/o potpis/pismo kralja implicira puninu. Njegova ruka do dna čitka i njegova ljubav do dna pitka svjedoče potpunu jasnoću i davanje bez ostatka. I dok je na planu sadržaja dočaran proljetni nemir i razbuđenost, na planu izraza, moglo bi se metaforički reći, i jezik je u svojevrsnom cvjetanju: novim glagolima (zabreziti, zasvibiti), melodioznošću i slikovitošću iskaza. Ono što postaje moguće na planu označitelja, istovremeno je nezamislivo na planu označenog. Pjesnički jezik labavi, u običnom govoru inače okoštale, veze označitelja i označenog stvarajući nove, neuobičajene veze koje ne postoje ni u zbilji ni u svakodnevnom govoru. Pjesnički jezik postaje, takoreći, mekan, fluidan, poput žitke mase pogodne za modeliranje novih mogućnosti značenja, zbilja biva proširena jezikom, univerzum jezičnog iskustva se širi. Novonastale veze pak ne djeluju neprirodno ili slučajno. I cijela je pjesma, takoreći, fluidna. Ritam čitanja zahvaljujući zvukovnim efektima nema rezova ni kidanja. Nova sintagmatska veza do dna pitka ljubav sažeto iskazuje ono što bi u običnom govoru trebalo biti ili razvučeno u duge sintagmatske lance u pokušaju obuhvaćanja svih mogućih konotacija koje se tu nadaju, ili raščarano ustaljenim (dosadnim) sintagmama poput čista ljubav, potpuna ljubav. Međutim te ustaljene sintagme ne mogu uprizoriti ideju ljubavi kao bistre, duboke, svježe vode koja taži duboku žeđ, siti, koja se ne pije iz čaše, već prije sa samog izvora, zatim osjećaj zadovoljstva onog koji je ugasio žeđ takvom ljubavlju itd. Znači inače semantički veoma udaljene značenjske cjeline približavaju se pjesničkim jezikom. Ono što je u zbilji apstraktno, 
kruto, neopipljivo, u pjesmi je prikazano kao tekuće. Osim ljubavi to je i mjesec/mjesečina, mjesec škropi. Škropljenje istovremeno asocira na škropljenje svetom vodom, što je u skladu s atmosferom cijele pjesme kao obredne, otajstvene. Slikovitost postaje bujnija kada zamislimo škropljenje svjetlošću i sjajem. Semantički okvir koji pjesma zacrtava širi se upravo time što pjesnički jezik izmiče logikama svakidašnje komunikacije te proširuje područje iskustva. Međutim ulazak u pjesmu bez obzira na novo jezika i dalje je moguć jer imamo na umu pretpostavku da je svaki čitatelj sigurno iskusio buđenje proljeća, buđenje bića, erotiku predigre i susret s nagovještajem punine, žeđ za ljubavlju itd. pa mu pjesma neće biti krajnje tuđa, hermetična. Uza sve ovo što se uspjelo imenovati pjesma međutim govori i o nečemu što se ne može konačno imenovati. Kazivo i nekazivo međusobno se uvjetuju i harmonično nadopunjuju te dodatno produbljuju pjesmu. Ova pjesma posve irelevantnim čini pitanja gdje, tko i kada, a ne možemo reći ni da smo čitajući ovu pjesmu došli do neke spoznaje o sebi, zbilji ni da se tajna pjesme otkrila uistinu. Osim što se u pjesmi eksplicite spominje riječ tajna, koja je svadbeno raskošna i kojom zveckaju otkrića, i cijela ova pjesma ostaje u svojoj zagonetnosti. To ne sprečava čitatelja da se baškari u raskošnoj igri njezina jezika. Autorica izmišlja nove glagole (zabreziti, zasvibiti), čime se pojačava dojam proljetnog bunila i stvara svojevrsna eufonija. Zato sam u radu i spomenula da pjesnički jezik nikako ne teži šutnji kao krajnosti koja ukida istinski govor, a koju kritika vrlo često stavlja u konačni cilj pjesme. Po mojem sudu jezik pjesme ima moć da, sažimajući, širi (jezičnu) zbilju ispreplićući kazivo i nekazivo. Nekazivo je tu, u blizini riječi, kao aura riječi. Riječ postaje bremenita. Tajna je uprisutnjena jezikom. Ono što niče iz tih začudnih spojeva istovremeno izmiče običnom govoru, drugim riječima, ova se pjesma jednostavno ne može prepričati, a da se bitno ne raščara i ne razvuče. Ono što dakle niče iz riječi, nije svodivo na riječ. Javljaju se nove dimenzije značenja koje nisu izravno denotirane. Plan označenog biva tako istovremeno izvan i unutar jezika. Doslovnog značenja tu nema niti treba biti. Moglo bi se reći da nije smisao pjesme da izriče smisao, semantički gledano sklopovi rečenica su uvelike nejasni. No istovremeno bilo bi neistinito kada bismo rekli da se pjesničkim jezikom smisao skriva ili da ga uopće nema. Naprotiv, elastičnošću jezika otvaraju se nove ili mnoge mogućnosti smisla, smisao se naslućuje, on se ne dokučuje.

Pjesme iz druge autoričine faze mahom tu slutnju pretvaraju u znanje. Pjesnički jezik više ne buja na granicama slutnje/tajne, nego biva osiromašen izričući istinu. Više nema jezične igre, tih riječi-stepenica koje vode dublje. 
Jezik je ogoljen idejom koju obznanjuje. I dok u prvoj pjesmi pjesnički jezik uprisutnjuje Tajnu, a da je ne odgonetava, u drugoj odgonetnutom Tajnom jezik biva pojednostavljen i pretvoren u sredstvo za prenošenje poruke istine.

\section{BUDI PONOSNA - NE BUDI OHOLA}

Budi ponosna - ne budi ohola.

Znaš li razliku?

Ponosni su oni koji znaju da su od Tvorca, oholi su oni koji misle da su oni tvorci.

Budi veličanstveno blaga; dostojanstveno čedna.

Otkrit ću ponosne, razotkriti ohole, čedne i tihe ću razglasiti, veličanstvene

u sjaj zaogrnuti.

Budi bezimeno slavna, budi bez imena poznata.

Onakva kakav sam Ja: slava sam svakog sveca, Ime sam svih imena.

(Krmpotić 1983)

Moglo bi se reći da je u prvoj pjesmi riječ svrha, a u drugoj sredstvo. Ako slijedimo utabane puteve grafičkog izgleda pjesme, s obzirom na to da su stihovi pisani italikom i s obzirom na to da je osobna zamjenica pisana velikim slovom, ovu bi se pjesmu imalo čitati kao obraćanje onostranog kroz zapisivačicu zapisivačici i čitateljima. Tvorac govori kao starozavjetni Jahve, strogo i opominjući. Pjesma je opomena. Ona je i naputak kako bi se trebalo vladati, osjećati, misliti, koji, ako se slijedi, obećava nagradu, ako ne, prijeti kaznom. Pjesma je pisana nepravilnim stihom mada ne bi zvučala nimalo drugačije da je pisana kao prozni tekst. Iako i u drugoj pjesmi doista ostaje zagonetno tko je lirski ja, kome se on obraća, tko su ispravni, tko pogrešni (tj. ostaje zagonetno ako ne slijedimo autoričine naputke iz autopoetičkih tekstova), jezik ove pjesme ne proizvodi prenesena značenja (tekst nije mnogoznačan), ne približava slutnji, ne začarava. Jezik se ne širi, zbilja ostaje dana/zadana. Sintagmatske veze ne spajaju međusobno udaljene semantičke cjeline da bi proizvele tajanstveno označeno. Procjep između označitelja i označenog bitno je sužen, ne mami na pokušaj premošćivanja slutnjom čime tekst pjesme postaje vrlo brzo iscrpiv. Čitatelj koji ulazi u prostor ove pjesme stavljen je u poziciju da može poslušati nalog pjesme ili ne mora, drugim riječima, njegovo kretanje u pjesmi bitno je ograničeno. Semantički okvir koji zacrtava pjesma, držim, čitatelj dodatno širi svojim učitavanjima. Prostranost pjesme se postiže, po mojem sudu, upravo labavljenjem odnosa označitelj - označeno, spajanjem nespojivog. 
Značenjsko uslojavanje omogućuje prostor za učitavanje. Više nije samo važno ono što je rečeno nego i ono što nije, što se tek naslućuje. Upravo na taj način postignuta prostranost omogućuje, rekla bih, osim slojevitijeg, dalekosežnijeg učitavanja, i cjelovitiji angažman čitatelja. U prilog tome išlo bi i to da, uz sva nastojanja da se u obje, za analizu izabrane pjesme, uđe što temeljitije, analiza druge pjesme i dalje ostaje trostruko kraća od analize prve pjesme. Naposljetku postavlja se pitanje je li grafička intervencija dovoljna za tuđost teksta? Moja je teza da grafički oblik nije dostatan da bude nositelj tuđosti. Ovaj drugi slučaj upućuje na to da ono što je u pjesmi tuđe jest sam subjekt iskaza. Pjesma se svodi na jasnu konstataciju, na golu misao, te se insinuira da se u njoj onostranost ozbiljuje kao lirski subjekt i svjedoči svoje prisustvo. Ipak, Tajna kao prisno tuđe u drugoj je pjesmi, po mojem sudu, odsutna. Tajna kao prisno tuđe prisutnija je u prvom primjeru gdje se ozbiljila jedinstvenim spajanjem označitelja.

Pustolovina jezika započinje u radu s nepoznanicom. Na taj rad nagoni ga žudnja. Za žudnju su bitne dvije oblasti od kojih je jedna diskurzivnog karaktera, a druga nije. Pritom prva mora biti prepoznata kao nedostatna.

\section{LITERATURA}

Anić, Vladimir. 2000. Rječnik hrvatskog jezika. Zagreb: Novi Liber.

Barbarić, Damir. 1995. Grčka filozofija. Zagreb: Školska knjiga.

Brnčić, Jadranka. 2012. Svijet teksta: uvod u Ricoeurovu hermeneutiku. Zagreb: Naklada Breza.

Chevalier, Jean. 1983. Rječnik simbola. Zagreb: Nakladni zavod Matice hrvatske.

Clark, Timothy. 2000. The theory of Inspiration: Composition As a Crisis of

Subjectivity in Romantic and Post-Romantic Writing. Manchester; New York: Manchester University Press.

Culler, Jonathan. 1981. The Persuit of Signs: Semotics, Literature, Deconstruction. New York: Cornell University Press.

De Rougemont, Denis. 1974. Ljubav i zapad. Zagreb: Nakladni zavod Matice hrvatske.

Demos, Raphael. 1934. Eros. „Journal of Philosophy”, 31, 13, 337-345.

Evans, Dylan [ur.]. 2001. An introductory dictionary of Lacanian psychoanalysis. London; New York: Brunner-Routledge.

Furniss, Tom, Bath, Michael. 2007. Reading Poetry: An Introduction. New York: Routledge.

Gavran, Zdravko. 2007. Između identiteta i svega. Pod svodovima svoga neba: književni ogledi i kritike. Zagreb: Naklada ,Jurčić”, 139-145. 
Heidegger, Martin. 2002. „...pjesnički obitava čovjek...“ Hölderlinove himne „Germanija” $i$,Rajna”. Zagreb: Demetra, 273-287.

Jacobus, Mary. 1985. Apostrophe and lyric voice in The prelude. Lyric poetry: beyond new criticism [ur. Chaviva Hošek i Patricia Parker]. Ithaca; London: Cornell University Press, 167-181.

Johnston, William. 2007. Mistična teologija: znanost ljubavi. Zagreb: Demetra.

Kojeve, Alexandre. 1990. Kako čitati Hegela. Sarajevo: „Veselin Masleša”; „Svjetlost”.

Krmpotić, Vesna. 1975. Dijamantni faraon: antologija središnjeg glasa. Zagreb: Znanje.

Krmpotić, Vesna. 1983. Vilin svlak. Zagreb: Prosvjeta.

Krmpotić, Vesna. 1989. Košulja sretnog čovjeka: filozofske i druge priče. Zagreb: Globus.

Krmpotić, Vesna. 1995. Stotinu i osam: knjiga trideset i šesta. „Republika”, 50, 9-10, 96-112.

Krmpotić, Vesna. 1997. Unus ad unam: zbirka poezije. Zagreb: V.B.Z.

Krmpotić, Vesna. 1999. Sedam koraka oko vatre: po knjigama pod naslovom Stotinu $i$ osam, a po brojevima 62, 63, 64, 65, 66, 67, 68 i 69. Zagreb: V.B.Z.

Macan, Trpimir [ur.]. 2013. Hrvatski biografski leksikon. Zagreb: Leksikografski zavod Miroslav Krleža.

Nygren, Anders. 1953. Agape and Eros. Philadelphia: The Westminister Press.Plato. 1970. Ijon; Gozba; Fedar. Beograd: Kultura.

Rajan, Tilottama. 1985. Romanticism and the death of lyric conciousness. Lyric poetry: beyond new criticism [ur. Chaviva Hošek i Patricia Parker]. Ithaca; London: Cornell University Press., 194-207.

Šalat, Davor. 2013. Nutrina je pravi izgled svijeta: razgovor s Vesnom Krmpotić, dobitnicom Nagrade „Tin Ujević” za 2013. godinu. „Kolo”, 5, 5-13.

Tucker, Herbert F. 1985. Dramatic monologue and the overhearing of lyric. Lyric poetry: beyond new criticism [ur. Chaviva Hošek i Patricia Parker]. Ithaca; London: Cornell University Press, 226-243.

Valdes, Mario J. [ur.]. 1991. Poetry and Possibility: An Interview with Paul Ricoeur. A Ricoeur Reader: Reflection and Imagination. Toronto; Buffalo: University of Toronto Press. 448-462.

Zima, Zdravko. 2000. Kronika jednog hodočašća. Porok pisanja: književni portreti.

Zagreb: SysPrint, 157-163. 


\section{SUMMARY \\ THE OTHERNESS OF POEM \\ (THE LYRIC OF VESNA KRMPOTIĆ)}

This dissertation analyses the relationship between desire for transcendence and the poetic language of Vesna Krmpotić as the medium of that desire. The influence of desire for transcendence on the poetic language itself ultimately leads to the question of what the (real) object of poetic desire is. In essence, the author's poetic world is shaped around the lyrical subject's desire to reveal the Secret, and for the Secret to become Knowledge. In this work the Secret is interpreted as the poem's Other, (familiar) unfamiliarity, as something that is, but does not know what it is. The Secret is outside of language, but influences the language, the language represents it, but cannot uncover it. The Secret is also the result of language and it is closely related to the poem. The Secret is not related to knowledge, but to premonition. As opposed to such conception, in the poetry of Vesna Krmpotic the Secret is equal to the Voice imposing the Truth. The dissertation examines the implications of such an approach to the Secret in the poetry of Vesna Krmpotić, as well as to the understanding and interpretation of poetry as such. In this work Vesna Krmpotić's poetry has been divided into two stages: before and after 1990. In the first stage the lyrical subject addresses the voiceless Other, while in the second stage the Other gains its voice. By relating the desire for transcendence to poems and encouraged by Krmpotić's idea of unfamiliarity of the source of a poem, this dissertation refers to Western philosophy (Plato, Heidegger), which is a completely new approach with regard to the former critical evaluations which mostly relied on Eastern philosophy. The reading of Vesna Krmpotić's poetry is also analysed within the framework of contemporary theoretical approaches to poetry and literature (Clark, Culler, Furniss, Bath), opposing them to the cultural tradition that connects poetry with pseudo-divine acts.

Key words: Secret, Other, unfamiliarity, voice, spirit, desire for transcendence, poetic language, poetic reality, expressible, inexpressible 